\title{
Front Matter: Volume 8618
}

, "Front Matter: Volume 8618," Proc. SPIE 8618, Emerging Digital Micromirror Device Based Systems and Applications V, 861801 (15 March 2013); doi: $10.1117 / 12.2022921$

SPIE. Event: SPIE MOEMS-MEMS, 2013, San Francisco, California, United States 


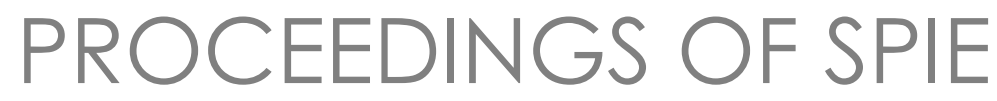

\title{
Emerging Digital Micromirror Device Based Systems and Applications V
}

\author{
Michael R. Douglass \\ Patrick I. Oden \\ Editors
}

5-6 February 2013

San Francisco, California, United States

Sponsored by

SPIE

Cosponsored by

DLP Texas Instruments (United States)

VUZIX Corporation (United States)

Supported by

Fraunhofer Institute for Photonic Microsystems (Germany)

Published by

SPIE 
The papers included in this volume were part of the technical conference cited on the cover and title page. Papers were selected and subject to review by the editors and conference program committee. Some conference presentations may not be available for publication. The papers published in these proceedings reflect the work and thoughts of the authors and are published herein as submitted. The publisher is not responsible for the validity of the information or for any outcomes resulting from reliance thereon.

Please use the following format to cite material from this book:

Author(s), "Title of Paper," in Emerging Digital Micromirror Device Based Systems and Applications $V$, edited by Michael R. Douglass, Patrick I. Oden, Proceedings of SPIE Vol. 8618 (SPIE, Bellingham, WA, 2013) Article CID Number.

ISSN: 0277-786X

ISBN: 9780819493873

Published by

SPIE

P.O. Box 10, Bellingham, Washington 98227-0010 USA

Telephone +1 3606763290 (Pacific Time) · Fax +1 3606471445

SPIE.org

Copyright (@ 2013, Society of Photo-Optical Instrumentation Engineers.

Copying of material in this book for internal or personal use, or for the internal or personal use of specific clients, beyond the fair use provisions granted by the U.S. Copyright Law is authorized by SPIE subject to payment of copying fees. The Transactional Reporting Service base fee for this volume is $\$ 18.00$ per article (or portion thereof), which should be paid directly to the Copyright Clearance Center (CCC), 222 Rosewood Drive, Danvers, MA 01923. Payment may also be made electronically through CCC Online at copyright.com. Other copying for republication, resale, advertising or promotion, or any form of systematic or multiple reproduction of any material in this book is prohibited except with permission in writing from the publisher. The CCC fee code is 0277-786X/13/\$18.00.

Printed in the United States of America.

Publication of record for individual papers is online in the SPIE Digital Library.

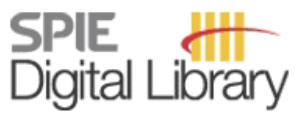

SPIEDigitallibrary.org

Paper Numbering: Proceedings of SPIE follow an e-First publication model, with papers published first online and then in print and on CD-ROM. Papers are published as they are submitted and meet publication criteria. A unique, consistent, permanent citation identifier (CID) number is assigned to each article at the time of the first publication. Utilization of CIDs allows articles to be fully citable as soon as they are published online, and connects the same identifier to all online, print, and electronic versions of the publication. SPIE uses a six-digit CID article numbering system in which:

- The first four digits correspond to the SPIE volume number.

- The last two digits indicate publication order within the volume using a Base 36 numbering

system employing both numerals and letters. These two-number sets start with 00, 01, 02, 03, 04, $05,06,07,08,09,0 A, 0 B \ldots$. 0Z, followed by 10-1Z, 20-2Z, etc.

The CID Number appears on each page of the manuscript. The complete citation is used on the first page, and an abbreviated version on subsequent pages. Numbers in the index correspond to the last two digits of the six-digit CID Number. 


\section{Contents}

vii Conference Committee

ix Introduction

xi Towards future systems with nano-optics contributions (Plenary Paper) [8616-101] B. Kaminska, Simon Fraser Univ. (Canada) and NanoTech Security Corp. (Canada); M. Najiminaini, Simon Fraser Univ. (Canada), Lawson Health Research Institute (Canada), and The Univ. of Western Ontario (Canada); Y. Chuo, C. Landrock, B. Omrane, Simon Fraser Univ. (Canada) and NanoTech Security Corp. (Canada); J. J. L. Carson, Lawson Health Research Institute (Canada) and The Univ. of Western Ontario (Canada)

xxvii MOEMS pressure sensors for geothermal well monitoring (Plenary Paper) [86 16-102] W. Challener, S. Palit, General Electric Global Research (United States); R. Jones, L. Airey, R. Craddock, General Electric Measurement and Control (United Kingdom); A. Knobloch, General Electric Global Research (United States)

SESSION 1 BIOMEDICAL IMAGING AND CELL MANIPULATION USING A DMD OR MEMS ARRAY I: JOINT SESSION WITH CONFERENCES 8587 AND 8618

861802 Medical applications of fast 3D cameras in real-time image-guided radiotherapy (IGRT) of cancer (Invited Paper) [8618-1]

S. Li, Temple Univ. Hospital (United States); T. Li, J. Geng, Xigen LLC (United States)

861803 Performance assessment of 3D surface imaging technique for medical imaging applications [8618-2]

T. Li, J. Geng, Xigen LLC (United States); S. Li, Temple Univ. Hospital (United States)

861804 Automatic respiration tracking for radiotherapy using optical 3D camera [8618-3]

T. Li, J. Geng, Xigen LLC (United States); S. Li, Temple Univ. Hospital (United States)

861805 Spectral light source distribution variations to enhance discrimination of the common bile duct from surroundings in reflectance hyperspectral images [8618-4]

M. Litorja, National Institute of Standards and Technology (United States); M. Fein, Oberlin College (United States); E. Wehner, The Univ. of Texas at Arlington (United States);

R. Schwarz, The Univ. of Texas Southwestern Medical Ctr. at Dallas (United States); K. Zuzak, Digital Light Innovations (United States); E. Livingston, Journal of the American Medical Association (United States) 
SESSION 2 BIOMEDICAL IMAGING AND CELL MANIPULATION USING A DMD OR MEMS ARRAY II: JOINT SESSION WITH CONFERENCES 8587 AND 8618

861806 In-vivo quantitative evaluation of perfusion zones and perfusion gradient in the deep inferior epigastric artery perforator flap (Invited Paper) [8618-5]

M. Saint-Cyr, Mayo Clinic (United States) and The Univ. of Texas Southwestern Medical Ctr. at Dallas (United States); C. Lakhiani, A. Cheng, The Univ. of Texas Southwestern Medical Ctr. at Dallas (United States); M. Mangum, The Univ. of Texas Southwestern Medical Ctr. at Dallas (United States), The Univ. of Texas at Arlington (United States), and Digital Light Innovations (United States); J. Liang, Digital Light Innovations (United States); S. Teotia, The Univ. of Texas Southwestern Medical Ctr. at Dallas (United States); E. H. Livingston, The Univ. of Texas Southwestern Medical Ctr. at Dallas (United States) and The Univ. of Texas at Arlington (United States); K. J. Zuzak, The Univ. of Texas Southwestern Medical Ctr. at Dallas (United States) and Digital Light Innovations (United States)

861807 Hyperspectral image segmentation of the common bile duct [8618-6]

D. Samarov, National Institute of Standards and Technology (United States); E. Wehner, The Univ. of Texas at Arlington (United States); R. Schwarz, The Univ. of Texas Southwestern Medical Ctr. at Dallas (United States); K. Zuzak, Digital Light Innovations (United States); E. Livingston, Journal of the American Medical Association (United States)

861808 Fluorescence image detection and reconstruction by subtractive light illumination using a digital micromirror device [8618-7]

J. Choi, D. Kim, Yonsei Univ. (Korea, Republic of)

861809 Attenuation corrected fluorescence extraction using spatial frequency domain imaging system [8618-8]

B. Yang, M. Sharma, Y. Wang, J. W. Tunnell, The Univ. of Texas at Austin (United States)

SESSION 3 SPATIAL LIGHT MODULATOR: JOINT SESSION WITH CONFERENCES 8616 AND 8618

$86180 \mathrm{~A}$ Additive manufacturing of photopolymers using the Texas Instruments DLP lightcrafter [8618-9]

M. Hatzenbichler, Technische Univ. Wien (Austria); M. Geppert, R. Seemann, FOTEC Forschungs- und Technologietransfer $\mathrm{GmbH}$ (Austria); J. Stampfl, Technische Univ. Wien (Austria)

\section{SESSION 4 SPECTROSCOPY AND HYPERSPECTRAL IMAGING}

8618 OB Testing of digital micromirror devices for space-based applications [8618-10]

K. Fourspring, Z. Ninkov, Rochester Institute of Technology (United States); S. Heap, Space Telescope Science Institute (United States); M. Roberto, NASA Goddard Space Flight Ctr. (United States); A. Kim, Lawrence Berkeley National Lab. (United States)

$86180 \mathrm{C}$ Full-frame programmable spectral filters based on micro-mirror arrays [8618-11] S. P. Love, D. L. Graff, Los Alamos National Lab. (United States) 
8618 OD Infrared adaptive spectral imagers for direct detection of spectral signatures and hyperspectral imagery [8618-12]

N. Goldstein, M. Fox, S. Adler-Golden, B. Gregor, Spectral Sciences, Inc. (United States)

8618 OE DMD-based multi-object spectrograph on Galileo telescope [8618-13]

F. Zamkotsian, Lab. d'Astrophysique de Marseille, CNRS (France); P. Spano, INAF Osservatorio Astronomico di Brera (Italy); P. Lanzoni, W. Bon, Lab. d'Astrophysique de Marseille, CNRS (France); M. Riva, INAF - Osservatorio Astronomico di Brera (Italy); L. Nicastro, INAF - IASF Bologna (Italy); E. Molinari, INAF - Telescopio Nazionale Galileo (Spain); P. Di Marcantonio, INAF - Osservatorio Astronomico di Trieste (Italy); F. Zerbi, INAF Osservatorio Astronomico di Brera (Italy); L. Valenziano, INAF - IASF Bologna (Italy)

8618 OF Real-time matched-filter imaging for chemical detection using a DMD-based programmable filter [8618-14]

D. L. Graff, S. P. Love, Los Alamos National Lab. (United States)

\section{SESSION 5 3D MEASUREMENT SYSTEMS USING STRUCTURED LIGHT}

$8618 \mathrm{OH}$ Binary pattern codification strategies in an active stereoscopic system based on flexible image guides [8618-16]

E. Dupont, Y. Hou, F. Lamarque, Lab. Roberval, Univ. de Technologie Compiègne (France);

T. Redarce, Lab. Ampère, CNRS, Institut National des Sciences Appliquées (France)

8618 0l Multi-wavelength compressive computational ghost imaging [8618-17]

S. S. Welsh, M. P. Edgar, The Univ. of Glasgow (United Kingdom); P. Jonathan, Lancaster Univ. (United Kingdom); B. Sun, M. J. Padgett, The Univ. of Glasgow (United Kingdom)

8618 0J Single image method to depict 3D profiles [8618-33]

M. Kondiparthi, Indian Institute of Science (India)

\section{SESSION 6 BEAM SHAPING AND SPECIAL IMAGE ENCODING}

8618 OK Using digital mirror devices and compressive imaging framework to achieve geometric superresolution and field of view extension (Invited Paper) [8618-18]

A. Zlotnik, Z. Afik, I. Layani, Z. Zalevsky, Bar-Ilan Univ. (Israel)

8618 OL DMD-based scanning of steep wavefronts for optical testing of freeform optics [8618-19] S. Stuerwald, Fraunhofer-Institut für Produktionstechnologie (Germany); R. Schmitt, Fraunhofer-Institut für Produktionstechnologie (Germany) and RWTH Aachen Univ. (Germany)

8618 OM Encoding complex values using two DLP spatial light modulators [8618-20] M. F. Becker, S.-Y. Wu, The Univ. of Texas at Austin (United States); J. Liang, Washington Univ. in St. Louis (United States)

8618 ON DMD as a diffractive reconfigurable optical switch for telecommunication [8618-21] P.-A. Blanche, D. Carothers, J. Wissinger, N. Peyghambarian, College of Optical Sciences, The Univ. of Arizona (United States) 


\section{SESSION 7 ADVANCED AND IMMERSIVE DISPLAYS}

8618 OP An interactive multiview 3D display system [8618-23]

Z. Zhang, Z. Geng, M. Zhang, H. Dong, Institute of Automation (China)

8618 OQ Single DMD time-multiplexed 64-views autostereoscopic 3D display [8618-24]

L. Loreti, L.B. Opto S.r.I. (Italy)

8618 OR High-dynamic range DMD-based IR scene projector [8618-25]

J. R. Dupuis, D. J. Mansur, R. Vaillancourt, R. Benedict-Gill, S. P. Newbry, OPTRA, Inc. (United States)

Author Index 


\title{
Conference Committee
}

\author{
Symposium Chair
}

Harald Schenk, Fraunhofer Institute for Photonic Microsystems

(Germany)

Symposium Cochair

David L. Dickensheets, Montana State University (United States)

Conference Chairs

Michael R. Douglass, Texas Instruments Inc. (United States)

Patrick I. Oden, Texas Instruments Inc. (United States)

Conference Program Committee

Michael F. Becker, The University of Texas at Austin (United States)

Hal Bellis, Keynote Technologies, LLC (United States)

Sara L. Best, University of Wisconsin School of Medicine and Public Health (United States)

Jason Geng, Xigen, LLC (United States)

Benjamin L. Lee, Texas Instruments Inc. (United States)

Raecine Meza, Texas Instruments Inc. (United States)

Yuval Kapellner Rabinovitz, EKB Technologies Ltd. (United States)

Paul Rancuret, Texas Instruments Inc. (United States)

Charley Yongzhi Yang, Wintech Digital Systems Technology

Corporation (United States)

Karel J. Zuzak, Digital Light Innovations (United States)

Session Chairs

1 Biomedical Imaging and Cell Manipulation using a DMD or MEMS

Array I: Joint Session with Conferences 8587 and 8618

Karel J. Zuzak, Digital Light Innovations (United States)

James F. Leary, Purdue University (United States)

2 Biomedical Imaging and Cell Manipulation using a DMD or MEMS

Array II: Joint Session with Conferences 8587 and 8618

Karel J. Zuzak, Digital Light Innovations (United States)

James F. Leary, Purdue University (United States)

3 Spatial Light Modulator: Joint Session with Conferences 8616 and 8618

Harald Schenk, Fraunhofer Institute for Photonic Microsystems

(Germany) 
4 Spectroscopy and Hyperspectral Imaging

Raecine Meza, Texas Instruments Inc. (United States)

Paul Rancuret, Texas Instruments Inc. (United States)

5 3D Measurement Systems Using Structured Light

Michael F. Becker, The University of Texas at Austin (United States)

Hal Bellis, Keynote Technologies, LLC (United States)

6 Beam Shaping and Special Image Encoding

Yuval Kapellner Rabinovitz, EKB Technologies Ltd. (United States)

Benjamin L. Lee, Texas Instruments Inc. (United States)

$7 \quad$ Advanced and Immersive Displays

Charley Yongzhi Yang, Wintech Digital Systems Technology

Corporation (United States)

Jason Geng, Xigen, LLC (United States) 


\section{Introduction}

We are once again pleased to have chaired a MOEMS/MEMS conference at SPIE Photonics West 2013. For the fifth year, our conference on Emerging DMD-Based Systems and Applications $\vee$ was an exciting forum for presenting and networking with colleagues in this internationally recognized symposium.

The Digital Micromirror Device (DMD) was conceived at Texas Instruments in 1987, following a decade of work on analog deformable-mirror and cantilever-mirror devices. This particular MOEMS device has been applied most famously to conference room and portable projectors, large-screen high-definition televisions, and digital cinema projection systems, all of which were enabled by DLP® technology.

As evidenced in this well-attended conference at Photonics West 2013, the DMD and associated development platforms are enabling many exciting new systems and applications beyond the traditional display technologies. The goal of this conference was to bring together scientists, technologists, and developers working on applications in these emerging markets. In that regard, it was a rousing success. In these proceedings, you will find 24 very interesting papers covering a wide range of applications. We categorized them into 7 separate sessions.

Session 1 - Biomedical Imaging and Cell Manipulation using a DMD or MEMS Array 1

Session 2 - Biomedical Imaging and Cell Manipulation using a DMD or MEMS Array II

Session 3 - Spatial Light Modulators - Applications (Additive Manufacturing)

Session 4 - Spectroscopy and Hyperspectral Imaging

Session 5 - 3D Measurement Systems Using Structured Light

Session 6 - Beam Shaping and Special Image Encoding

Session 7 - Advanced and Immersive Displays.

Sessions 1 and 2 were joint sessions with BIOS conference 8587, "Imaging, Manipulation, and Analysis of Biomolecules, Cells, and Tissues." This provided some great interaction between BIOS and MEMS conferences highlighting ways to use MEMS to improve medical research.

Our four invited authors are considered experts in their fields and we are honored that they participated in our conference. They and the other authors shared their progress on developing new applications using a DMD to process and manipulate light. 
We want to thank our program committee for the great work they did developing the conference theme, finding all these wonderful speakers, and organizing the papers into a cohesive structure. Special thanks go to the session chairs for working with their authors, coordinating the conference and keeping it on schedule. And of course extra special thanks to the authors who did a fantastic job presenting their subjects in an interesting and passionate way. You made the conference a success.

We also want to thank Dr. Harald Schenk and Dr. David Dickensheets (symposium chair and cochair) for their support and guidance. And of course thanks to the SPIE staff for keeping us on task.

If you were able to attend the conference, we know you enjoyed it and are looking forward to reading more about these interesting DMD applications. For those that did not attend, we hope you enjoy reading the papers as well. Keep those innovations coming; who knows what might be around the next corner.

\section{Michael R. Douglass} Patrick I.Oden 